\title{
Structure and properties of silver-doped calcium phosphate nanopowders
}

\author{
RAVINDER PAL SINGH* and UMA BATRA \\ Department of Materials and Metallurgical Engineering, PEC University of Technology, Chandigarh 160012, India
}

MS received 20 October 2015; accepted 8 February 2016

\begin{abstract}
Stable and antimicrobial silver-doped calcium phosphate nanopowders were synthesized using sol-gel route by setting the atomic ratio of $\mathrm{Ag} /(\mathrm{Ag}+\mathrm{Ca})$ at $3 \%$ and $(\mathrm{Ca}+\mathrm{Ag}) / \mathrm{P}$ at 1.67. Prior to synthesis of nanopowders, influence of time of hydrolyzation on $\mathrm{pH}$ and density of precursors were comprehensively studied. Hydrolyzation time was found to have profound influence on $\mathrm{pH}$ of constituent precursors. Sufficient hydrolysis resulted in early maturation of sol. Scanning electron microscopy (SEM) showed the heterogeneous and agglomerated state of particles with average size of $3.9 \pm 1.9 \mu \mathrm{m}$. Energy dispersive X-ray spectroscopy (EDX) presented uniform distribution of $\mathrm{O}, \mathrm{Ag}, \mathrm{Ca}$ and $\mathrm{P}$ elements in nanopowder. Fourier transform infrared spectroscopy (FTIR) confirmed the formation of apatitic structure, whereas X-ray diffraction (XRD) revealed the multiphase constitution of nanopowders primarily composed of $\beta$-TCP, Ag and other hybrid phases. Crystallite size and lattice parameters of $\beta$-TCP and Ag phases were increased with the rise in calcination temperature. Thermogravimetric analysis (TGA) showed three regions of weight change and indicated the high thermal stability of nanopowders. Disk diffusion method was used to test the antimicrobial resistance of nanopowders against Escherichia coli and Staphylococcus aureus bacterial strains. All nanopowders exhibited antimicrobial resistance against both $E$. coli and $S$. aureus bacteria.
\end{abstract}

Keywords. Sol-gel processes; calcination; electron microscopy; antimicrobial.

\section{Introduction}

Success and long-term survival of orthopedic implants in human body depends on the prevention of bacterial infection which is usually encountered following the implant placement [1]. Infection is one of the devastating reasons which severely reduces the lifespan of the implants and increases their failure rates [2]. One simple and accepted strategy to treat and prevent infections associated with orthopedic implants is to deliver antibiotics in a controlled manner at the site of implantation [3-5]. Among the antibiotics, ionic heavy metals, such as $\mathrm{Ag}^{+}, \mathrm{Zn}^{2+}$ and $\mathrm{Cu}^{2+}$ are efficient, stable and can be easily carried by calcium phosphate (CP)-based powders doped through ionic substitution or co-precipitation methods.

$\mathrm{Ag}$ shows a broad spectrum of antibacterial activity and possesses many advantages, such as excellent biocompatibility, satisfactory stability [6,7] and exhibits low toxicity towards mammalian cells [8]. Ag particles bind to the bacterial cell wall and cell membrane and inhibit their respiration process $[9,10]$. All common bacterial strains involved in implant-associated infections can be eliminated by $\mathrm{Ag}$ [2]. Influence of Ag concentration on physico-chemical and antimicrobial resistance of hydroxyapatite (HAP) nanopowders has been discussed by many workers [11-15]. Low concentrations of Ag lack the toxicity on the mammalian cells [16-18], but its high concentration could have toxic effects [1].

*Author for correspondence (er.ravinderpalsingh@gmail.com)
Ion exchange method is widely used for doping of $\mathrm{Ag}$ into HAP nanopowders. The limitation of this method is that the antimicrobial agent accumulates onto the surface and quickly depletes without long-term antimicrobial effect [12]. But, through sol-gel route, the substituted ions directly insert into the lattice structure of matrix elements $[2,16]$ and produce stable compounds $[17,19]$.

In this paper, sol-gel route was employed to synthesize $\mathrm{Ag}$-doped calcium phosphate $(\mathrm{Ag}-\mathrm{CP})$ nanopowders. $\mathrm{Ag}$ concentration of $3 \mathrm{wt} \%$ has been suggested as an optimum dose with highest antimicrobial resistance along with least cytotoxic properties and therefore, was selected for the present investigation. Besides the detailed examination of physico-chemical properties of $\mathrm{Ag}-\mathrm{CP}$ nanopowders, influence of time of hydrolyzation on $\mathrm{pH}$ and density of constituent precursors were also examined. Disk diffusion method was used to examine the antimicrobial resistance of synthetic nanopowders against microbiological assays of Gram negative Escherichia coli and Gram positive Staphylococcus aureus bacteria.

\section{Materials and methods}

Calcium nitrate tetrahydrate (CNT, Merck, 98\%), triethyl phosphite (TEP, Spectrochem, 98\%) and silver nitrate $\left(\mathrm{AgNO}_{3}\right.$, Merck, $\left.99.9 \%\right)$ were used as $\mathrm{Ca}, \mathrm{P}$ and $\mathrm{Ag}$ ion sources, respectively. Double-distilled water (DDW) and ethanol (Merck, 99.9\%) were used as solvents. Ammonium hydroxide $\left(\mathrm{NH}_{4} \mathrm{OH}\right.$, Merck, $\left.25 \%\right)$ was used to improve the gelation. Synthesis procedure is detailed in figure 1. 


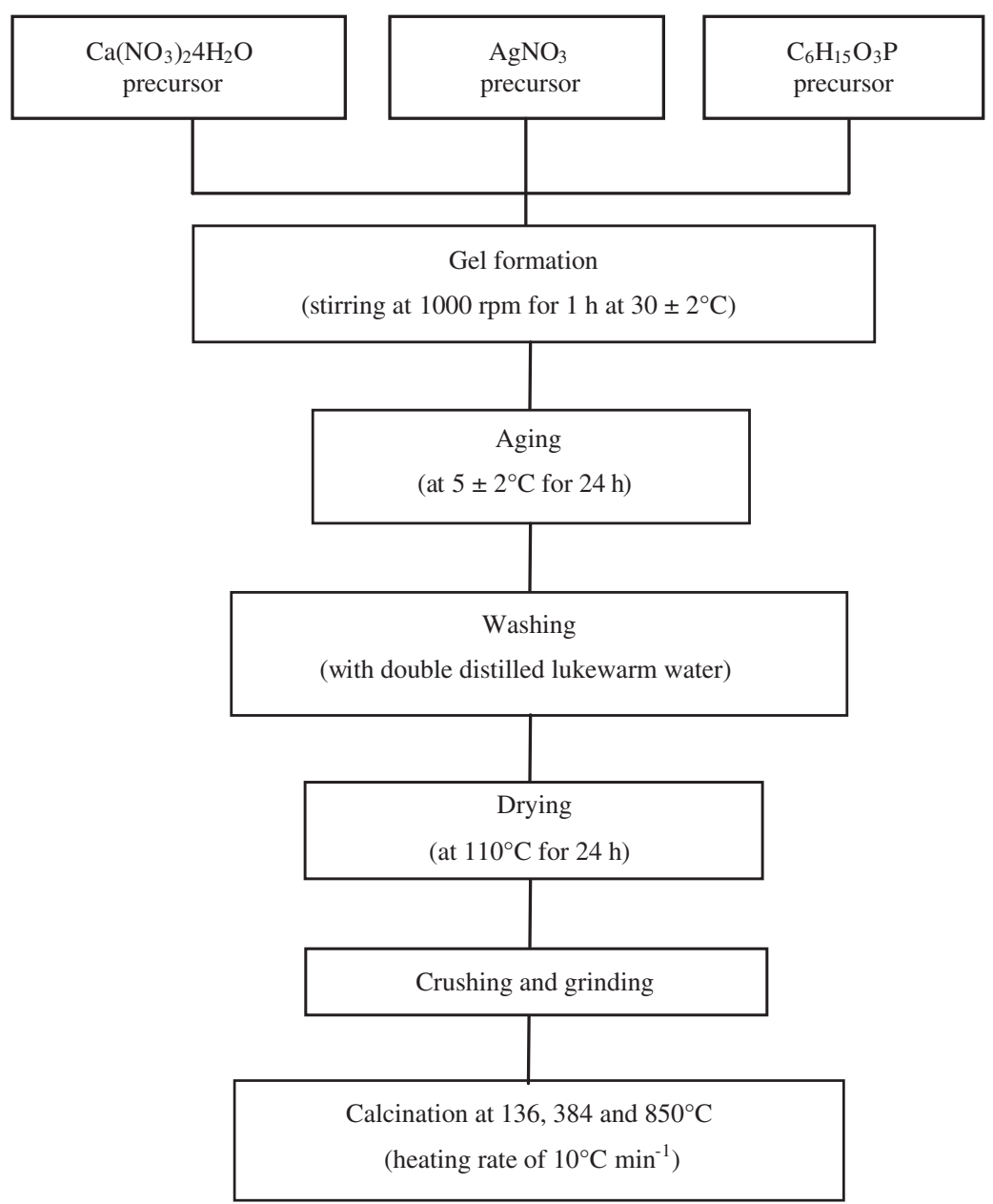

Figure 1. Synthesis procedure.

\subsection{Sol characterization}

Digital $\mathrm{pH}$ meter (MAX, India) and digital weighing-cumdensity meter (Denver, SI-234) were used to measure the $\mathrm{pH}$ and density of solutions, respectively.

\subsection{Powder characterization}

Particle morphology was examined using scanning electron microscopy (SEM, JEOL), operated at $15 \mathrm{kV}$. Elemental composition of nanopowder was examined using colour mapping technique of energy dispersive spectroscopy (EDX).

Fourier-transform infrared spectra (FTIR, Perkin Elmer) were recorded in the range of $400-4000 \mathrm{~cm}^{-1}$ using $\mathrm{KBr}$ pellets $(1 \% \mathrm{wt} / \mathrm{wt})$ with spectral resolution of $2 \mathrm{~cm}^{-1}$ and taking 32 scans for each sample.

X-ray diffraction (XRD, Philips X'Pert 1710) analysis was performed using $\mathrm{CuK} \alpha$ radiation $(\lambda=1.54 \AA$, $2 \theta=10$ $80^{\circ}$, step size $0.017^{\circ}$, time per step $20.03 \mathrm{~s}$ and scan speed $0.005^{\circ} \mathrm{s}^{-1}$ ). Relative amount of detected phases were estimated on the basis of the peak intensity variation by means of external standard method. Lattice parameters for $\beta$-TCP and Ag phases were calculated using equations (1) and (2), respectively:

$$
\begin{aligned}
& \frac{1}{d^{2}}=\frac{4}{3}\left\{\frac{h^{2}+h k+k^{2}}{a^{2}}\right\}+\frac{l^{2}}{c^{2}}, \\
& \frac{1}{d^{2}}=\frac{h^{2}+k^{2}+l^{2}}{a^{2}},
\end{aligned}
$$

where $d$ is the distance between adjacent planes in the set of Miller indices $(h k l)$. The JCPDS file nos. 01-070-0364 for $\beta$-TCP, 01-071-4613 for Ag (cubic, $a=4.086 \mathrm{~nm}$ ), 01-0841261 for silver oxide, 01-082-0807 for calcium phosphide, 00-054-1098 for silver calcium phosphate and 01-084-0511 for trisilver phosphate (cubic, $a=6.011 \mathrm{~nm}$ ) were used.

Crystallite size $\left(X_{\mathrm{S}}\right)$ was calculated using Scherrer's formula (equation 3):

$$
X_{\mathrm{S}}=\frac{0.9 \lambda}{\beta \cos \theta},
$$

where $X_{\mathrm{S}}$ is in nanometer, $\lambda$ the wave length of $\mathrm{X}$-ray beam, $\beta$ the broadening of diffraction line at half of its maximum intensity in radians and $\theta$ the Bragg's diffraction angle $\left(^{\circ}\right)$. 
The silicon standard was used to measure the instrument broadening to correct the value of $\beta$.

Thermal behaviour of nanopowder was investigated using thermogravimetry (TG) (Perkin Elmer STA 6000) analyzer with an accuracy of $\pm 0.1 \mu \mathrm{g}$ in weight measurement and $\pm 0.5^{\circ} \mathrm{C}$ in temperature measurement. Test was performed in air environment under the conditions: heating rate $10^{\circ} \mathrm{C}$ $\mathrm{min}^{-1}$, peak temperature $1000^{\circ} \mathrm{C}$ and air flow $20 \mathrm{ml} \mathrm{min}^{-1}$.

Antimicrobial resistance of nanopowders was tested against E. coli and $S$. aureus bacteria using disk diffusion method. The inoculums of microorganisms were prepared from fresh overnight broth cultures incubated at $37^{\circ} \mathrm{C}$. Agar was poured into petri dishes to form thick layers and dense inoculums of the tested microorganisms were added to them. Petri plates were left for $10 \mathrm{~min}$ to dry in air. Nanopowders were put into the wells on the agar surface and incubated for $24 \mathrm{~h}$ at $37^{\circ} \mathrm{C}$. Diameter of inhibition zones $(\mathrm{mm})$ were taken as the measurement of antimicrobial resistance.

\section{Results and discussion}

\subsection{Hydrolysis of precursors}

Precursors of CNT, TEP and $\mathrm{AgNO}_{3}$ were hydrolysed at $30 \pm 2^{\circ} \mathrm{C}$ for six days and their $\mathrm{pH}$ and density are shown in figure 2. The $\mathrm{pH}$ of CNT precursor was increased from 4.45

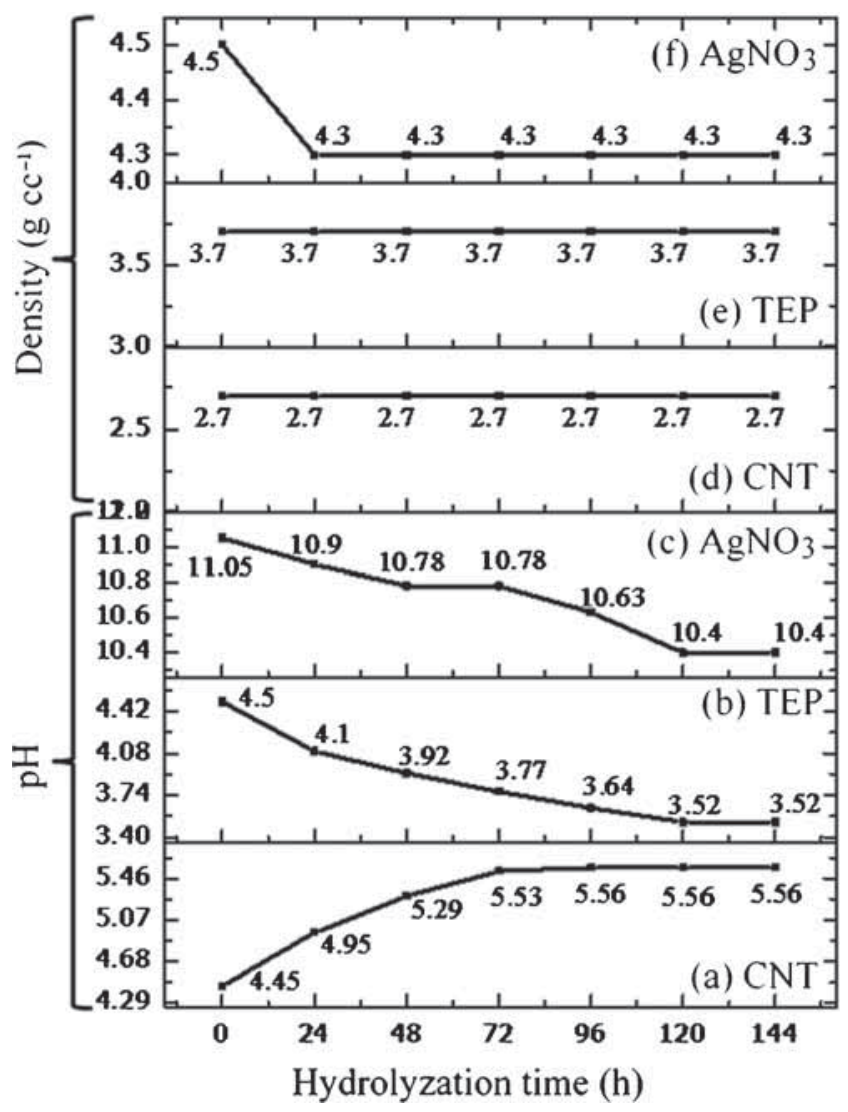

Figure 2. Influence of hydrolyzation time on $\mathrm{pH}$ : (a) CNT, (b) TEP, (c) $\mathrm{AgNO}_{3}$ and density, (d) CNT, (e) TEP and (f) $\mathrm{AgNO}_{3}$ precursors. to 5.56 during $96 \mathrm{~h}$ of hydrolysis, revealing its denitrification. The $\mathrm{pH}$ of TEP and $\mathrm{AgNO}_{3}$ precursors was decreased up to $120 \mathrm{~h}$ as shown in figure $2 \mathrm{~b}$ and $\mathrm{c}$, which indicated the continuous release of protons (liberation of $\mathrm{H}^{+}$) in them. Density of CNT and TEP precursors were remained unchanged, whereas density of $\mathrm{AgNO}_{3}$ precursor decreased minutely as shown in figure $2 \mathrm{~d}-\mathrm{f}$, respectively. Optically, CNT and TEP precursors were remained transparent, whereas $\mathrm{AgNO}_{3}$ precursor was remained carbon black in colour throughout hydrolysis.

\subsection{Preparation of $A g-C P$ sol}

Matured CNT, TEP and $\mathrm{AgNO}_{3}$ precursors were mixed together and formed $\mathrm{Ag}-\mathrm{CP}$ sol. Incorporation of $\mathrm{Ag}$ ions into apatitic solution is based on equation (4) as suggested by Lim et al [20].

$$
\begin{aligned}
& (10-x) \mathrm{Ca}^{2+}(\mathrm{aq})+x \mathrm{Ag}^{+}(\mathrm{aq})+6 \mathrm{PO}_{4}^{3-}(\mathrm{aq}) \\
& +(2-x) \mathrm{OH}^{-}(\mathrm{aq}) \rightarrow \mathrm{Ca}_{10-x} \mathrm{Ag}_{x}\left(\mathrm{PO}_{4}\right)_{6}(\mathrm{OH})_{2-x}(\mathrm{aq})
\end{aligned}
$$

Milky white solution was developed upon the addition of $\mathrm{AgNO}_{3}$ precursor into CNT precursor. Addition of TEP precursor transformed the resultant Ag-CP sol through various colour changes i.e., turned into light orange to red colour and finally to black colour during continuous stirring. No gelation was observed throughout the stirring. To cause precipitation, $\mathrm{NH}_{4} \mathrm{OH}$ was added into $\mathrm{Ag}-\mathrm{CP}$ sol till its $\mathrm{pH}$ increased to 10. Optically, black coloured Ag-CP sol turned into light grey colour along with the development of gelation. The $\mathrm{pH}$ and density of Ag-CP sol were remained stable at 10 and $3.1 \mathrm{~g} \mathrm{cc}^{-1}$, respectively, throughout the ageing time period of $24 \mathrm{~h}$.

Ammonia reacts readily with Ag ions in the basic conditions and form diamine silver (I) ion and reduces the incorporation of $\mathrm{Ag}$ ions into the apatite structure as suggested by various authors [20-22].

\subsection{Morphological and elemental properties of nanopowder}

Owing to its maximum crystallinity, Ag-CP nanopowder calcined at $850^{\circ} \mathrm{C}$ (Ag-CP-850) were characterized for particle shape, size and distribution. SEM micrographs of Ag-CP-850 nanopowder are shown in figure 3. Particles were aggregates of heterogeneous shapes and sizes. Spherical, elongated and small plate like particles were observed as shown in figure 3. Average particle size was $3.9 \pm 1.9$ $\mu \mathrm{m}$, whereas average size of agglomerates was $4.4 \pm 2.1 \mu \mathrm{m}$. Large surface area and high surface energy were usually associated with the nanoparticles which cause the particles to agglomerate.

Coagulation of HAP/Ag particles has been reported by Diaz et al [14]. Iqbal et al [23] reported agglomerated spherical morphology of HAP/Ag nanoparticles with particle size range of $80-85 \mathrm{~nm}$. Ciobanu et al [24] reported ellipsoidal 

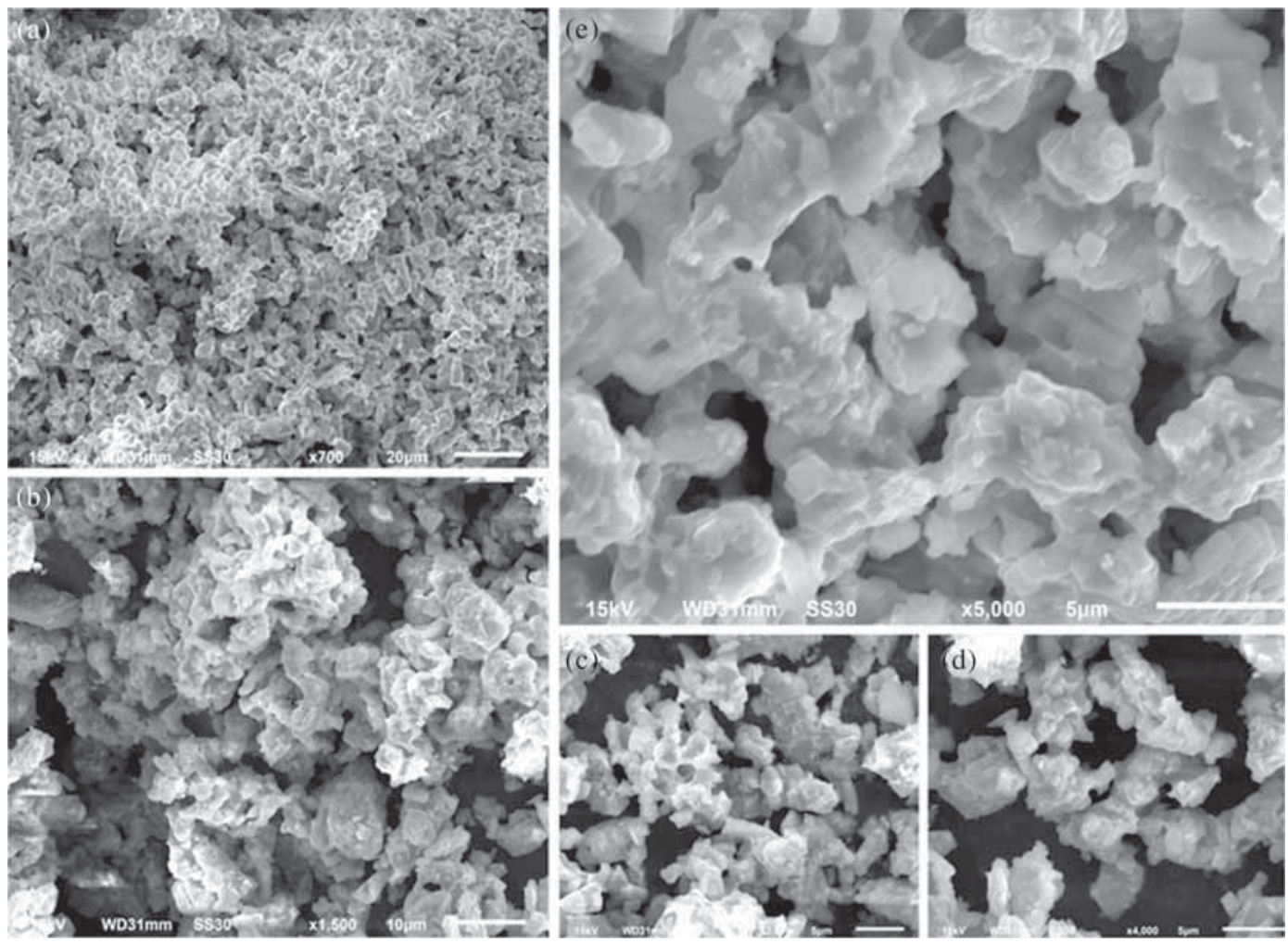

Figure 3. Particle morphology and distribution of Ag-CP-850 nanopowders shown at different magnifications.


Figure 4. Elemental composition and distribution in Ag-CP-850 nanopowder. 
morphology of HAP/Ag $\left(0.2<x_{\mathrm{Ag}}<0.4\right)$ particles. Size and shape of particles would influence their antimicrobial efficacy as reported by many workers [25-28]. Nanoparticles have large surface area and cause high percentage of interaction with bacterial cells than bigger particles as suggested by many workers [27-30]. According to Pal et al [28], truncated triangular nanoparticles showed bacterial inhibition with $\mathrm{Ag}$ content of $1 \mu \mathrm{g}$, whereas in case of spherical nanoparticles, total $\mathrm{Ag}$ content of $12.5 \mu \mathrm{g}$ was needed. The rod-shaped particles needed 50-100 $\mu \mathrm{g}$ of Ag content.

Elemental composition and spread in $\mathrm{Ag}-\mathrm{CP}-850$ nanopowder is shown in figure 4. Uniform spread of $\mathrm{O}, \mathrm{Ca}, \mathrm{P}$ and $\mathrm{Ag}$ elements was noticed. The $\mathrm{Ca} / \mathrm{P}$ molar ratio was 1.16 which inferred that some $\mathrm{Ca}^{2+}$ ions in the apatite lattice were replaced or occupied by $\mathrm{Ag}^{+}$ions as suggested by Yang et al [31]. $\mathrm{Ca} / \mathrm{O}$ ratio was 0.45 which was close to the standard value of 0.30 for HAP nanoparticles.

Ciobanu et al [12,24] and Iqbal et al [23] reported the presence of $\mathrm{O}, \mathrm{Ca}, \mathrm{P}$ and $\mathrm{Ag}$ elements in $\mathrm{HAP} / 0.2 \mathrm{Ag}$ doped nanopowders. Feng et al [32] reported 1.19 and 1.46 $\mathrm{Ca} / \mathrm{P}$ atomic ratio of coatings with and without Ag-treatment, respectively. They also reported the $(\mathrm{Ca}+\mathrm{Ag}) / \mathrm{P}$ molar ratio of 2.59 which was close to the similar ratio of 2.35 in the present study. Yang et al [31] reported $\mathrm{Ca} / \mathrm{P}$ molar ratio of 1.529 of porous HAP/Ag nanocomposites. Bai et al [33] deposited functionally graded HAP coatings having $3 \% \mathrm{Ag}$ content and detected $\mathrm{Ca} / \mathrm{P}$ molar ratio of $2.33 \pm 0.01$.

\subsection{Ionic structure}

FTIR spectra of as-prepared and calcined $\mathrm{Ag}-\mathrm{CP}$ nanopowders are shown in figure 5. Spectra confirmed the presence of apatitic peaks: structural $\mathrm{OH}^{-}\left(630 \mathrm{~cm}^{-1}\right), v_{1} \mathrm{PO}_{4}^{3-}$ $\left(962 \mathrm{~cm}^{-1}\right), v_{3} \mathrm{PO}_{4}^{3-}\left(1043 \mathrm{~cm}^{-1}\right)$ and $v_{3} \mathrm{HPO}_{4}^{3-}\left(1131 \mathrm{~cm}^{-1}\right)$ ions in as-prepared and calcined $\mathrm{Ag}-\mathrm{CP}$ nanopowders. Small peaks corresponding to $\mathrm{OH}^{-}$water $\left(1629 \mathrm{~cm}^{-1}\right), \mathrm{P}-\mathrm{OH}$ $\left(2462 \mathrm{~cm}^{-1}\right)$ and surface adsorbed water ions $\left(3392 \mathrm{~cm}^{-1}\right)$ were also present in as-prepared and $\mathrm{Ag}-\mathrm{CP}$ nanopowder calcined at $136^{\circ} \mathrm{C}(\mathrm{Ag}-\mathrm{CP}-136)$ as shown in figure $5 \mathrm{a}$ and $\mathrm{b}$. On calcination at $384^{\circ} \mathrm{C}(\mathrm{Ag}-\mathrm{CP}-384)$ and $850^{\circ} \mathrm{C}(\mathrm{Ag}-\mathrm{CP}-$ 850 ), peaks of $\mathrm{OH}^{-}$water and surface adsorbed water ions disappeared from the spectra as shown in figure $5 \mathrm{c}$ and $\mathrm{d}$. $\mathrm{CO}_{3}^{2-}$ peaks $\left(1300-1600 \mathrm{~cm}^{-1}\right)$ appeared in the spectra of Ag-CP-384 and Ag-CP-850 nanopowders, which indicated the formation of carbonated apatitic structure in these nanopowders. Some unwanted peaks which might belong to the compounds, used while making the pallets, were also detected in spectra of $\mathrm{Ag}-\mathrm{CP}-850$ nanopowder (figure 5d) and were not considered. High concentration of $\mathrm{PO}_{4}^{3-}$ ions suggested the formation of nonstoichiometric $\mathrm{Ca} / \mathrm{P}$ molar ratio in $\mathrm{Ag}-\mathrm{CP}$ nanopowders.

Presence of $\nu_{1} \mathrm{PO}_{4}^{3-}$ ion $\left(950-975 \mathrm{~cm}^{-1}\right)$ indicated the formation of $\beta$-TCP phase in $\mathrm{Ag}-\mathrm{CP}$ nanopowders as suggested by Vijayalakshmi and Rajeswari [34]. Disappearance of $\mathrm{OH}^{-}$and surface adsorbed water ions have suggested the substitution of $\mathrm{Ag}^{+}$into $\mathrm{Ca}^{2+}$ ions as reported by many workers $[12,24,35,36]$.

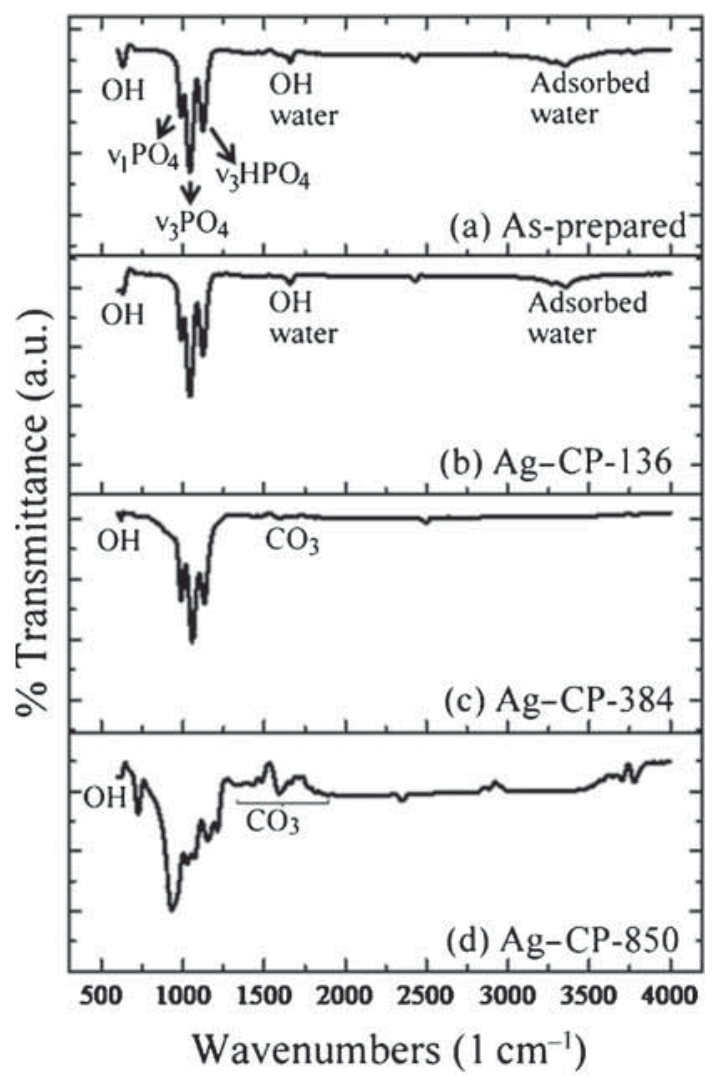

Figure 5. FTIR spectra of (a) as-prepared, (b) Ag-CP-136, (c) Ag-CP-384 and (d) Ag-CP-850 nanopowders.

\subsection{Phase constitution}

$\mathrm{XRD}$ patterns of as-prepared and calcined $\mathrm{Ag}-\mathrm{CP}$ nanopowders are shown in figure 6. XRD patterns revealed the multiphase constitution of nanopowders composed of $\beta$-TCP, calcium phosphide $\left(\mathrm{Ca}_{5} \mathrm{P}_{8}\right), \mathrm{Ag}$, silver oxide $\left(\mathrm{Ag}_{3} \mathrm{O}_{4}\right)$ and other hybrid phases as shown in figure 6. Presence of pure and oxide phases of $\mathrm{Ag}$ indicated the successful doping of $\mathrm{CaP}$ crystals with $\mathrm{Ag}$. Several reports have demonstrated the high reactivity of $\left(\begin{array}{lll}1 & 1 & 1\end{array}\right) \mathrm{Ag}$ facets [37-39]. Only $\beta$-TCP and trisilver phosphate $\left(\mathrm{Ag}_{3} \mathrm{PO}_{4}\right)$ phases were present in $\mathrm{Ag}-$ CP-850 nanopowder as shown in figure 6d. Development of trisilver phosphate phase suggested the chemical reaction of $\mathrm{Ag}$ with $\mathrm{PO}_{4}^{3-}$ ions. Satisfactory match in terms of peak positions and peak intensities in as-prepared and calcined $\mathrm{Ag}-\mathrm{CP}$ nanopowders was observed on comparing with the standard JCPDS files of constituent phases. Weight\% of constituent phases is mentioned in table 1.

The isolated (2 200$)$ and (2 14 ) reflections were used to calculate the crystallite size and lattice parameters of hexagonal $\beta$-TCP crystals, whereas (2 200$)$ and (3 111$)$ planes were used to calculate the crystallite size and lattice parameters of cubic Ag phase in Ag-CP nanopowders. Mean crystallite size and lattice parameters of $\beta$-TCP and Ag phases were increased with the rise in calcination temperature as mentioned in table 2. Lattice parameter of Ag crystal remained close to the standard value of 4.086 up to the calcination temperature of $136^{\circ} \mathrm{C}$. 


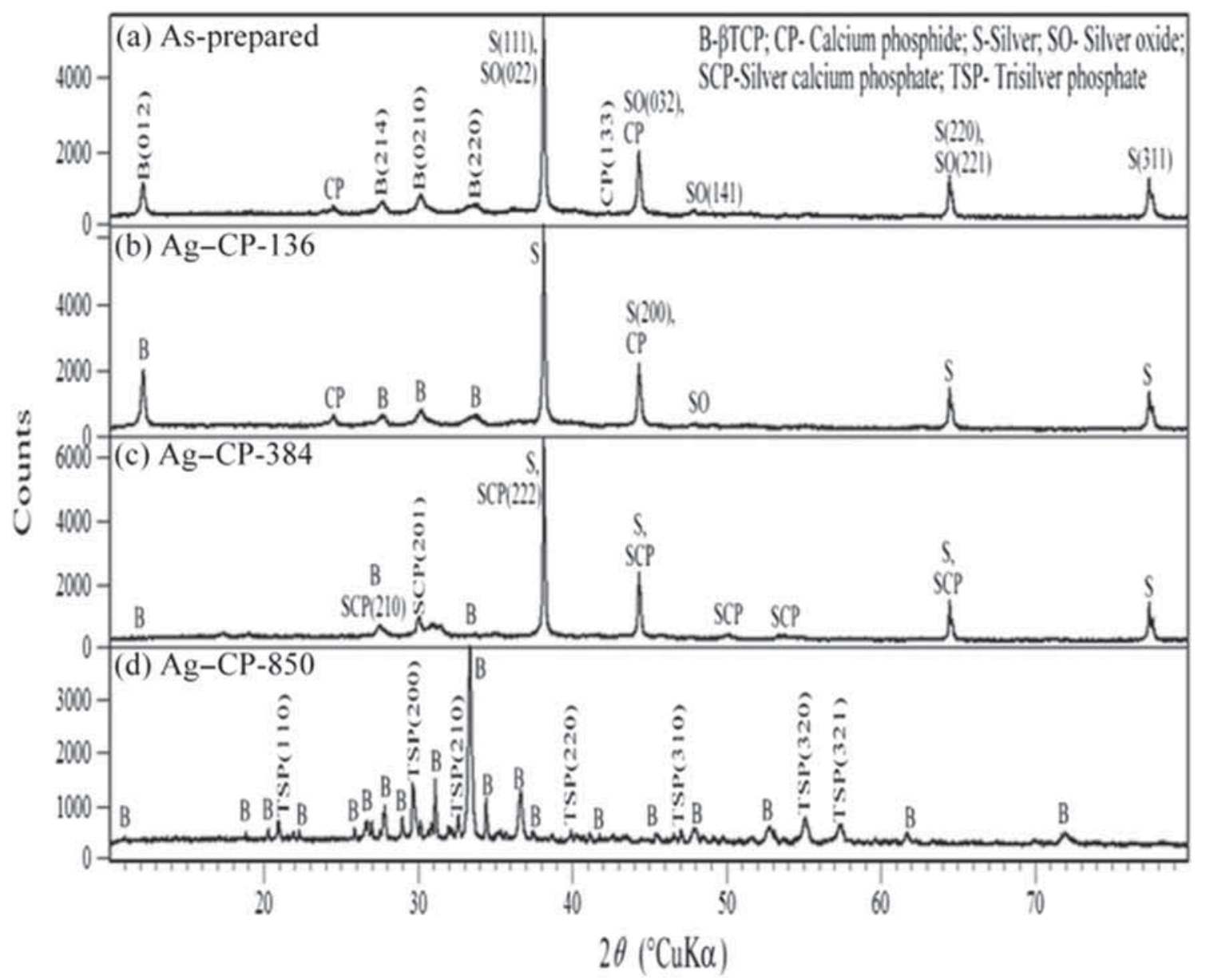

Figure 6. XRD patterns of (a) as-prepared, (b) Ag-CP-136, (c) Ag-CP-384 and (d) Ag-CP-850 nanopowders.

Table 1. Weight percentage of constituent phases in as-prepared and calcined $\mathrm{Ag}-\mathrm{CP}$ nanopowders.

\begin{tabular}{|c|c|c|c|c|}
\hline \multirow{2}{*}{$\begin{array}{l}\text { Weight } \\
\text { percentage }\end{array}$} & \multicolumn{4}{|c|}{ Nanopowders } \\
\hline & As-prepared & Ag-CP-136 & Ag-CP-384 & $\mathrm{Ag}-\mathrm{CP}-850$ \\
\hline$\beta$-ТCP & 51 & 51 & 15 & 61 \\
\hline $\mathrm{CP}$ & 9 & 11 & - & - \\
\hline $\mathrm{S}$ & 33 & 35 & 54 & - \\
\hline SO & 7 & 3 & - & - \\
\hline $\mathrm{SCP}$ & - & - & 31 & - \\
\hline TSP & - & - & - & 39 \\
\hline
\end{tabular}

Rameshbabu et al [15] produced HAP/Ag nanopowders and calcined below $700^{\circ} \mathrm{C}$ and reported single-phase apatite having low Ag content $(<1.63 \mathrm{wt} \%)$. However, $\beta$-TCP and Ag phosphate phases were developed, when heated above $700^{\circ} \mathrm{C}$ and metallic $\mathrm{Ag}$ was observed, when heated at $800^{\circ} \mathrm{C}$. Yang et al [31] observed HAP and Ag phosphate phases in co-precipitated porous HAP/Ag nanocomposites. The advantages of $\mathrm{Ag}$ phosphate phase compared to other $\mathrm{Ag}$ compounds are its low solubility in aqueous solutions and its high antibacterial efficiency as reported by Buckley et al [40] and Yi et al [41]. Diaz et al [14] detected no phases other than HAP and $\mathrm{Ag}$ in the nanocomposite of HAP/Ag prepared by co-precipitation method. Singh et al [11] reported phase-pure apatite having $\mathrm{Ag}$ content up to $2 \mathrm{wt} \%$. Iqbal et al [23] detected HAP, Ag and $\beta$-TCP phases in HAP/Ag nanopowders. Ciobanu et al [24] observed only HAP phase in HAP/Ag $\left(0.2<x_{\mathrm{Ag}}<0.4\right)$ nanopowders. A small peak of $\mathrm{Ag}$ phase among HAP peaks was detected in the coprecipitated composites of HAP/Ag nanopowders as reported by Iqbal et al [42]. Akhavan et al [43] observed monoclinic $\mathrm{Ag}$ and $\mathrm{Ag}$ phosphate phases in $\gamma$-irradiated HAP/Ag nanoparticles. Lim et al [20] reported thermal stability (up to $1150^{\circ} \mathrm{C}$ ) of co-precipitated phase-pure HAP/Ag nanoparticles containing $0.2-1.1 \mathrm{wt} \%$ of Ag.

Castanon et al [44] synthesized Ag particles of $25 \mathrm{~nm}$. Diaz et al [14] reported Ag particles of $65 \mathrm{~nm}$. Sygnatowicz et al [45] detected ( $\left.\begin{array}{lll}1 & 1 & 1\end{array}\right)$ and (2 00 ) planes of Ag particles of $\sim 100 \mathrm{~nm}$ crystallite size. Ciobanu et al [12] synthesized HAP/0.2 Ag nanoparticles using co-precipitation method and reported particle size of $\sim 40 \mathrm{~nm}$. Iqbal et al [42] reported crystallite size of $\mathrm{Ag}$ phase with a range of $18-33 \mathrm{~nm}$. Average size of HAP/Ag nanoparticles was $79 \pm 26 \mathrm{~nm}$ as reported by Mocanu et al [46]. Lattice parameters of HAP 
Table 2. Mean crystallite size and lattice parameters of $\beta$-TCP and Ag phases in as-prepared and calcined Ag-CP nanopowders.

\begin{tabular}{|c|c|c|c|c|}
\hline & \multicolumn{4}{|c|}{ Nanopowders } \\
\hline & As-prepared & Ag-CP-136 & Ag-CP-384 & $\mathrm{Ag}-\mathrm{CP}-850$ \\
\hline \multicolumn{5}{|c|}{ Mean crystallite size $(\mathrm{nm})$} \\
\hline$\beta$-ТCP & $22.3 \pm 6.1$ & $49 \pm 9.7$ & $53.4 \pm 11$ & $62.1 \pm 13$ \\
\hline $\mathrm{Ag}$ & $65.2 \pm 13$ & $89.2 \pm 5.1$ & $96.8 \pm 5$ & - \\
\hline \multicolumn{5}{|c|}{ Lattice parameters } \\
\hline \multicolumn{5}{|c|}{$\beta$-ТCP } \\
\hline$a(\AA)$ & 10.572 & 10.599 & 10.658 & 10.740 \\
\hline$c(\AA)$ & 33.555 & 34.645 & 34.948 & 35.355 \\
\hline$c / a$ & 3.17 & 3.26 & 3.27 & 3.29 \\
\hline \multicolumn{5}{|l|}{$\mathrm{Ag}$} \\
\hline$a(\AA)$ & 4.087 & 4.087 & 5.468 & - \\
\hline
\end{tabular}

in calcined HAP/Ag nanocomposites were: $a=9.38587 \pm$ $0.00267 \AA, c=6.85981 \pm 0.00398 \AA$ as revealed by Nath et al [36]. Lattice parameters of $a=b=9.435 \AA$, $c=$ $6.876 \AA$ for $x_{\mathrm{Ag}}=0.05 ; a=b=9.443 \AA, c=6.875 \AA$ for $x_{\mathrm{Ag}}=0.2$; and $a=b=9.445 \AA, c=6.877 \AA$ for $x_{\mathrm{Ag}}=0.3$ were reported by Ciobanu et al [44]. Ciobanu et al [24] revealed the lattice parameters of $a=b=9.422 \AA$ and $c=6.879 \AA$ with $x_{\mathrm{Ag}}=0.2 ; a=b=9.423 \AA$ and $c=6.878 \AA$ for $x_{\mathrm{Ag}}=0.3$ and $a=b=9.427 \AA$ and $c=6.877 \AA$ for $x_{\mathrm{Ag}}=0.4$, respectively.

\subsection{Thermal properties}

TG plot of as-prepared $\mathrm{Ag}-\mathrm{CP}$ nanopowder is shown in figure 7. Three regions of weight change marked as I, II and III were observed and are shown in figure 7. Region I: 30 $136^{\circ} \mathrm{C}$ (weight increased by $4.72 \%$ ), region II: $136-384^{\circ} \mathrm{C}$ (weight loss of $7.6 \%$ ) and region III: $384-850^{\circ} \mathrm{C}$ (weight increased by $3.8 \%$ ). Weight loss from 136 to $384^{\circ} \mathrm{C}$ was attributed to the escape of volatile $\mathrm{OH}$ and surface adsorbed water molecules. Weight loss of $\sim 7.6 \%$ indicated the high thermal stability of synthetic nanopowder. Due to the incorporation of $\mathrm{Ag}$ in the lattice, thermal stability of $\mathrm{CaP}$ powders increased as suggested by Nath et al [36]. It was supported by FTIR (figure 5) and XRD (figure 6) analyses also which revealed intact molecular and phase constitutions up to calcination temperature of $384^{\circ} \mathrm{C}$.

\subsection{Antimicrobial resistance}

As-prepared and calcined $\mathrm{Ag}-\mathrm{CP}$ nanopowders exhibited antimicrobial resistance against both $E$. coli and $S$. aureus bacteria, as inhibition zone developed around them as shown in figures 8 and 9. Pure $\mathrm{CP}$ nanopowders (without $\mathrm{Ag}$ ) calcined at $300,500,700$ and $900^{\circ} \mathrm{C}$ were also tested against both $E$. coli and $S$. aureus bacteria, but did not show antimicrobial resistance as shown in figure 10a and b. Structural and physico-chemical properties of these calcined $\mathrm{CP}$

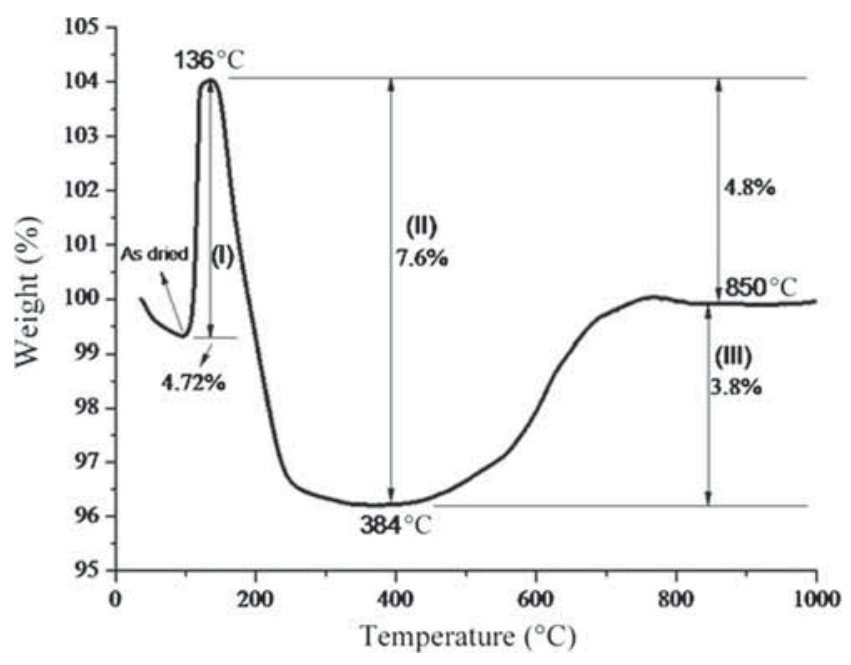

Figure 7. TG thermograph of as-prepared $\mathrm{Ag}-\mathrm{CP}$ nanopowder.

nanopowders have been published elsewhere [47]. Average diameter of inhibition zones developed against $E$. coli and S. aureus bacteria are mentioned in table 3 .

Calcined $\mathrm{Ag}-\mathrm{CP}$ nanopowders exhibited superior antimicrobial resistance than as-prepared nanopowders as indicated by the diameter of inhibition zones mentioned in table 3 . $\mathrm{Ag}-\mathrm{CP}$ nanopowders exhibited superior resistance against $S$. aureus bacteria than E. coli.

Actual bactericide mechanism of $\mathrm{Ag}$ nanoparticles is not well known as reported by many authors $[48,49]$. Some researchers support the idea that $\mathrm{Ag}$ species release $\mathrm{Ag}^{+}$ions and interact with thiol groups in bacteria proteins, affect their DNA and inhibit bacterial replication [50].

Rameshbabu et al [15] observed complete inhibition of S. aureus bacteria after $24 \mathrm{~h}$ in co-precipitated HAP/Ag nanopowders containing $0.5,1$ and $1.5 \mathrm{wt} \%$ of $\mathrm{Ag}$. Stanic et al [51] observed complete reduction of $S$. aureus bacteria after $4 \mathrm{~h}$ in co-precipitated nanodimensional HAP/Ag particles with $0.4 \mathrm{wt} \%$ of Ag. Singh et al [11] reported antibacterial effect against $E$. coli bacteria among co-precipitated 

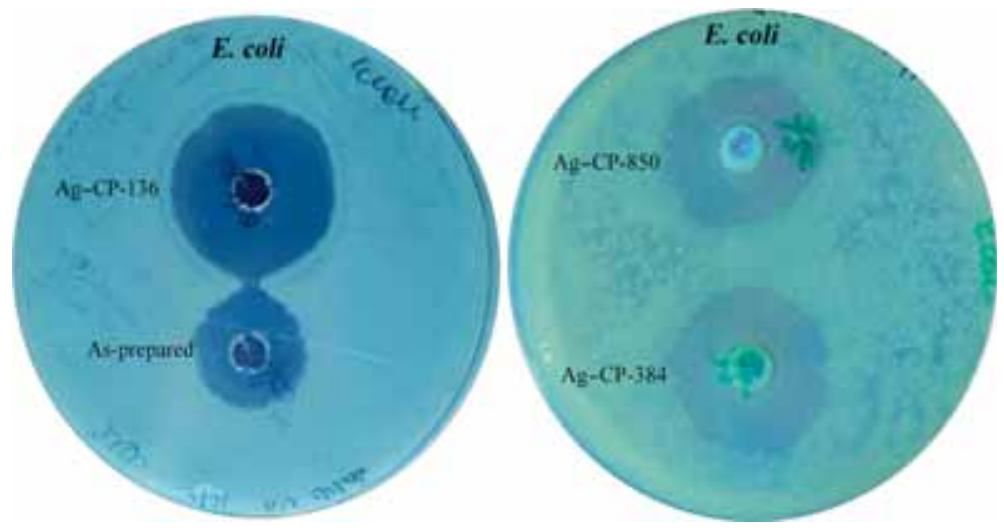

Figure 8. Inhibition zones developed around as-prepared and calcined $\mathrm{Ag}-$ $\mathrm{CP}$ nanopowders against $E$. coli bacteria.
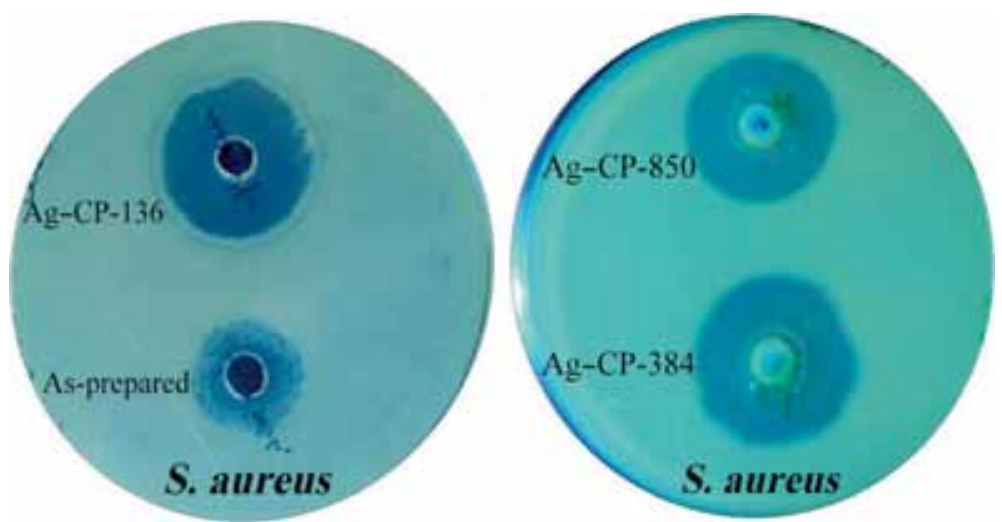

Figure 9. Inhibition zones developed around as-prepared and calcined Ag$\mathrm{CP}$ nanopowders against $S$. aureus bacteria.
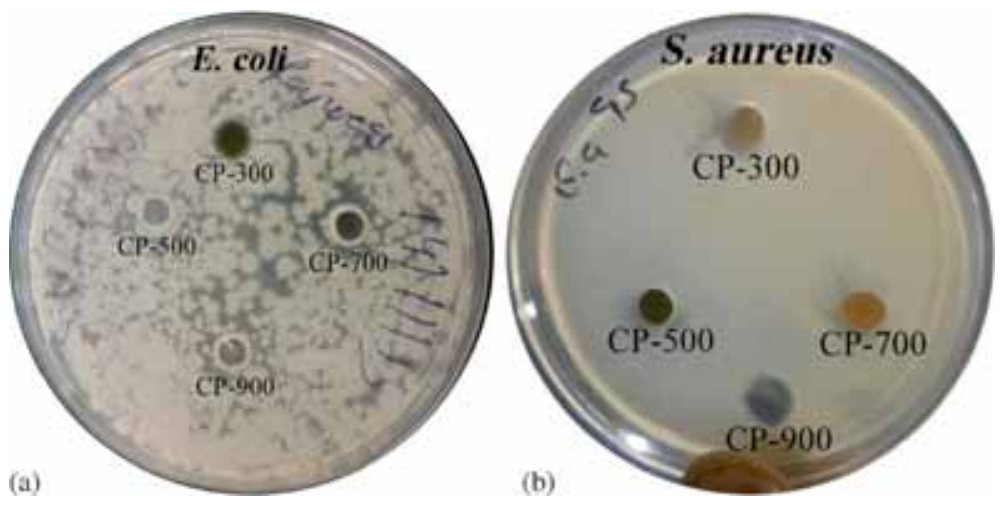

Figure 10. Petri dishes carrying calcined CP nanopowders tested against (a) E. coli and (b) S. aureus bacteria.

Table 3. Diameter of inhibition zones developed against E. coli and S. aureus bacteria.

\begin{tabular}{lcccccccc}
\hline & \multicolumn{7}{c}{ Inhibition zone diameter $( \pm 1 \mathrm{~mm})$} \\
\cline { 2 - 8 } Nanopowders & As-prepared & $\mathrm{Ag}-\mathrm{CP}-136$ & $\mathrm{Ag}-\mathrm{CP}-384$ & $\mathrm{Ag}-\mathrm{CP}-850$ & $\mathrm{CP}-300$ & $\mathrm{CP}-500$ & $\mathrm{CP}-700$ & $\mathrm{CP}-900$ \\
\hline E. coli & 15 & 22 & 50 & 48 & - & - & - & - \\
S. aureus & 41 & 56 & 60 & 56 & - & - & - & - \\
\hline
\end{tabular}


HAP/Ag particles containing Ag content of 2, 3 and $5 \mathrm{wt} \%$. However, HAP/Ag powders with $\mathrm{Ag}$ content greater than $3 \mathrm{wt} \%$ were cytotoxic towards mouse fibroblast cells. It has been suggested that $\mathrm{Ag}$ content between 0.5 and $3 \mathrm{wt} \%$ in co-precipitated HAP/Ag could achieve effective antibacterial effect [15,21,51]. A 3-log reduction of $S$. aureus population was observed in nanodimensional HAP/Ag particles containing $0.5,0.9,1$ and $1.1 \mathrm{wt} \%$ of $\mathrm{Ag}$ as reported by Lim et al [52]. Substitution of $0.5 \mathrm{wt} \%$ of Ag into HAP was sufficient to retard and inhibit the bacterial growth. HAP/Ag powders exhibited complete inhibition of E. coli bacteria after $24 \mathrm{~h}$ as reported by Akhavan et al [43]. Several antibacterial studies demonstrated that HAP/Ag (both co-precipitated and ion exchanged) nanopowders exhibited excellent antibacterial activity, with a reduction of more than $99 \%$ against almost all known bacteria as reported by Lim et al [20].

Diaz et al [14] reported inhibition zone diameters of $18 \pm 5$ and $17 \pm 0.5 \mathrm{~mm}$ developed around HAP/Ag nanopowders against E. coli and $S$. aureus bacteria, respectively. Mocanu et al [46] reported $10-15 \mathrm{~mm}$ and 11$16 \mathrm{~mm}$ inhibition zone diameters developed around HAP/Ag nanoparticles against $E$. coli and $S$. aureus bacteria, respectively. They also reported that $S$. aureus bacteria exhibited highest sensitivity against Ag nanoparticles, showing the largest zones of inhibition. Average diameter of inhibition zones were 4, 1 and $1 \mathrm{~mm}$ against $E$. coli, $S$. aureus and Candida albicans bacteria, respectively, exhibited by HAP/Ag nanopowders as revealed by Stanic et al [51]. Average inhibition zone diameters of HAP/0.3 Ag were $9,6,8$ and $10 \mathrm{~mm}$ against S. aureus, Bacillus subtilis, Pseudomonas aeruginosa and $E$. coli bacteria, respectively, whereas HAP/1 Ag resulted in the inhibition zones of 5, 9, 8 and $10 \mathrm{~mm}$, respectively. HAP/5 Ag showed inhibition diameters of 11, 9, 9 and $12 \mathrm{~mm}$ against $S$. aureus, B. subtilis, P. aeruginosa and $E$. coli bacteria, respectively, as reported by Iqbal et al [23].

\section{Conclusion}

Hydrolysis of constituent precursors must be completed before their mixing to form $\mathrm{Ag}-\mathrm{CP}$ sol. Synthetic nanopowder was the agglomerated mixture of spherical, elongated and small plate-like particles of vivid sizes. EDX confirmed the uniform spread of all desirable elements. FTIR and XRD examinations confirmed the Ag-doped apatitic structure of synthesized nanopowders. Mean crystallite size and lattice parameters of primary phases were increased with the rise in calcination temperature. TG test indicated the high thermal stability of synthesized nanopowders and supported XRD and FTIR interpretations. All synthetic nanopowders were potent against selected bacterial strains. Nanopowders exhibited maximum antibacterial resistance against $S$. aureus bacteria.

\section{References}

[1] Chen W, Liu Y, Courtney H S et al 2006 Biomaterials 27 5512
[2] Miranda M, Fernández A and Díaz M 2010 Int. J. Mater. Res. 101122

[3] Hendriks J G E, Horn J R V, Mei H C V and Busscher H J 2004 Biomater. 25545

[4] Gerhart T N, Roux R D and Hanff P A 1993 J. Orthopaed. Res. 11250

[5] Leach W J and Wilson N I L 1992 J. R. Col. Surg. Edinb. 37 265

[6] Zhao L, Chu P K and Zhang Y 2009 J. Biomed. Mater. Res. Part B: Appl. Biomater. 91470

[7] Babu R, Zhang J, Beckman E J et al 2006 Biomaterials 27 4304

[8] Park E J, Lee S W and Bang I C 2011 Nanoscale Res. Lett. 6 223

[9] Rai M, Yadav A and Gade A 2009 Biotechnol. Adv. 2776

[10] Feng Q L, Wu J and Chen G Q 2000 J. Biomed. Mater. Res. 52662

[11] Singh B, Dubey A K, Kumar S, Saha N, Basu B and Gupta R 2011 Mater. Sci. Eng. C 311320

[12] Ciobanu C S, Massuyeau F, Constantin L V et al 2011 Nanoscale Res. Lett. 6613

[13] Kim J S, Kuk E, Yu K N and Kim J H 2007 Nanomed. Nanotechnol. Biol. Med. 395

[14] Diaz M, Barba F, Miranda M, Guitian F, Torrecillas R and Moya J S 2009 J. Nanomater. 2009 doi: 10.1155/2009/498505

[15] Rameshbabu N, Kumar S T S, Prabhakar T G, Sastry V S, Murty K V G K and Prasad R K 2007 J. Biomed. Mater. Res. 80A 581

[16] Melaiye A and Youngs W J 2005 Expert Opin. 15125

[17] Mo A, Liao J and Xu W 2008 Appl. Surf. Sci. 255435

[18] Sondi I and Ba S S 2004 J. Coll. Interf. Sci. 275177

[19] Fielding G A, Roy M and Bandyopadhyay A 2012 Acta Biomater. 83144

[20] Lim P N, Chang L and Thian E S 2015 Nanomed.: Nanotechnol. Biol. Med. 111331

[21] Oh K S, Park S H and Jeong Y K 2004 Key Eng. Mater. 2642682111

[22] Zyman Z, Rokhmistrov D, Ivanov I and Epple M 2006 Materialwiss. Werkst. 37530

[23] Iqbal N, Kadir M R A and Malek N A Z N 2012 Mater. Lett. 89118

[24] Ciobanu C S, Iconaru S L, Chifiriuc M C, Costescu A, Coustumer P L and Predoi D 2013 Biomed. Res. Int. 2013 doi: $10.1155 / 2013 / 916218$

[25] Panacek A, Kvitek L, Prucek R, Kolar M, Vecerova R, Pizurova N, Sharma V K, Tatjana N and Zboril Z 2006 J. Phys. Chem. B 11016248

[26] Raimondi F, Scherer G G, Kotz R and Wokaun A 2005 Angew. Chem. Int. Edit. 442190

[27] Morones J R, Elechiguerra J L, Camacho A, Holt K, Kouri J B, Ramirez J T and Yacaman M J 2005 Nanotechnology 16 2346

[28] Pal S, Tak Y K and Song J M 2007 Appl. Environ. Microb. 731712

[29] Mulvaney P 1996 Langmuir 12788

[30] Kreibig U and Vollmer M 1995 Optical properties of metal clusters (Berlin, Germany: Springer)

[31] Yang L, Ning X, Xiao Q and Zhou K H 2007 J. Biomed. Mater. Res. Part B: Appl. Biomater. 81B 50

[32] Feng Q L, Kim T N, Wu J, Park E S, Kim J O, Lim D Y and Cui F Z 1998 Thin Solid Films 335214 
[33] Bai X, More K, Rouleau C M and Rabiei A 2010 Acta Biomater. 62264

[34] Vijayalakshmi U and Rajeswari S 2012 J. Sol-Gel Technol. 6345

[35] Jovanovic J, Adnadjevic B, Kicanovic M and Uskokovic D 2004 Colloids Surf. B: Biointerfaces 39181

[36] Nath S, Kalmodia S and Basu B 2010 J. Mater. Sci.: Mater. Med. 211273

[37] Smith D J, Petfordlong A K, Wallenberg L R and Bovin J O 1986 Science $\mathbf{2 3 3} 872$

[38] Liu H B et al 2001 Surf. Sci. 49188

[39] Yacaman M J, Asencio J, Liu H B and Gardea J J 2001 J. Vac. Sci. Technol. B 191091

[40] Buckley J J, Lee A F, Olivi L and Wilson K 2010 J. Mater. Chem. 208056

[41] Yi Z, Ye J, Kikugawa N, Kako T, Ouyang S, Stuart-Williams $\mathrm{H}$ et al 2010 Nat. Mater. 9559

[42] Iqbal N, Kadir M R A and Malek N A N N 2013 Mater. Res. Bull. 483172
[43] Akhavan A, Sheikh N, Khoylou F, Naimian F and Ataeivarjovi E 2014 Radiat. Phys. Chem. 9846

[44] Ciobanu C S, Iconaru S L, Coustumer P L, Constantin L V and Predoi D 2012 Nanoscale Res. Lett. 7324

[45] Sygnatowicz M, Keyshar K and Tiwari A 2010 J. Mater. 6265

[46] Mocanu A, Furtosa G, Rapuntean S, Horovitz O, Flore C, Garboa C et al 2014 Appl. Surf. Sci. 298225

[47] Singh R P and Batra U 2014 J. Chem. Pharm. Res. 6469

[48] Castanon G A M, Martınez N N, Gutierrez F M, Mendoza J R M and Ruiz F 2008 J. Nanopart. Res. 101343

[49] Li W R, Xie X B, Shi Q S, Duan S S, Ouyang Y S and Chen Y B 2011 Biometals 24135

[50] Marini M, De Niederhausern, Iseppi R, Bondi M, Sabia C, Toselli M and Pilati F 2007 Biomacromolecules 8 1246

[51] Stanic V, Janackovic D, Dimitrijevic S, Tanaskovic S B and Mitric M 2011 Appl. Surf. Sci. 2574510

[52] Lim P N, Teo E Y, Ho B, Tay B Y and Thian E S 2013 J. Biomed. Mater. Res. 101A 2456 